\title{
The measurement and interpretation methodology of resistivity logs affected by the Groningen effect - a Polish case study
}

\author{
Stanisław Baudzis ${ }^{1}$, Jadwiga A. Jarzyna ${ }^{2}$, Edyta Puskarczyk ${ }^{3}$ \\ ${ }^{1}$ Geofizyka Toruń S.A.; ul. B. Chrobrego 50,87-100 Toruń, Poland; e-mail: stanislaw.baudzis@geofizyka.pl \\ ${ }^{2} A G H$ University of Science and Technology, Faculty of Geology Geophysics and Environmental Protection; \\ al. A. Mickiewicza 30, 30-059 Krakow, Poland; ORCID ID: 0000-0002-1803-8643 \\ ${ }^{3}$ AGH University of Science and Technology, Faculty of Geology Geophysics and Environmental Protection; \\ al. A. Mickiewicza 30, 30-059 Krakow, Poland; ORCID ID: 0000-0001-5277-0507
}

\begin{abstract}
(C) 2020 Authors. This is an open access publication, which can be used, distributed and reproduced in any medium according to the Creative Commons CC-BY 4.0 License requiring that the original work has been properly cited.
\end{abstract}

Received: 26 February 2020; accepted: 28 March 2020; first published online: 8 May 2020

\begin{abstract}
True formation resistivity Rt measurement is one of the fundamental logs in the calculation of hydrocarbon resources. That is why it is very important to have the most reliable resistivity data possible. In this paper, the various outcomes obtained by Polish well log analysts and engineers for the proper determination of hydrocarbon saturation in the Main Dolomite deposits in the Polish Lowland are presented. The long history of efforts directed to make proper exploitation decisions in wells where the Groningen effect has been observed is illustrated, starting with the standard measurement and interpretational approach, through the modified construction of a reference electrode in a Laterolog device and ending with an examination of HRLA (High Resolution Laterolog Array) or Array Compensated Resistivity Tool) ACRt results. The processing of resistivity logs with the special Poprawki software is included.
\end{abstract}

Keywords: Groningen effect, Laterologs, induction tools, resistivity, hydrocarbon saturation

\section{INTRODUCTION}

Electrical tools, especially Laterologs, are an important part of logging sets used in resistivity measurements in boreholes drilled for hydrocarbon and water prospection. Curves from Dual Laterolog device (DLL) are frequently encountered in both current and archival well logging data sets (Schlumberger 1970, Woodhouse 1978, Chemali \& Dirk 1987). However, in highly resistive formations drilled with conductive water-based muds, DLL is an easy and effective tool which is indispensable for the true determination of resistivity. In the hydrocarbon prospecting industry, the resistivity of a zone which has been undisturbed by drilling processes or mud filtration is necessary to calculate proper water/hydrocarbon saturation (Ellis \& Singer 2008). In hard, fractured rocks, DLL can be used for the identification of fractured formations not only in hydrocarbon prospection but also in geothermal investigations (Boyeldieu \& Winchester 1982, Sibbit \& Faivre 1985, Vasvari 2011). There is a considerable amount of archive data, including Dual Laterolog and Dual Induction curves, which may be applied to the primary determination of resistivity anisotropy (Klein et al. 1997).

Service companies all over the world are still working on new methods and methodologies in well logging which are better than older ones thanks to new methodological approaches and modern technological solutions (Smits et al. 1995, 1998). At the same time, groups of computer 
science specialists have presented the results of the modeling of the responses of various resistivity logs using combined physical and mathematical algorithms (for instance, finite element modeling, FEM) to include the corrections to the old logs (Cozzolino \& Silva 2007, Drahos \& Galsa 2015, Szijártó et al. 2017, Xiao-Wei et al. 2017). Both technical and computational ways provide solutions which are appreciated by those working in hydrocarbon/water prospection because the proper determination of water/hydrocarbon saturation from the apparent/true resistivity recorded by electrical logs is still a problem in reservoir formations drilled by boreholes filled with very conductive mud, and where there exists a highly resistive bed in the vicinity of the reservoir.

The problem of correct water/hydrocarbon saturation calculation first arose when records of different types of resistivity logs were analyzed in the Groningen hydrocarbon deposit in the Netherlands, discovered in 1959 and exploited from this year onwards (Andersen 2001). The Groningen effect means an anomalously high resistivity reading on a LLD curve from a Laterolog device of the highest radius of investigation that occurs approximately $30 \mathrm{~m}$ below a thick, highly resistive bed such as the thick evaporitic Zechstein caprock in the Groningen field. Many constructive/tool design, modeling and interpretational solutions have been tested all over the world in the long period between the sixties and the present day (Yang et al. 2007, Nam et al. 2010, Cichy \& Ossowski 2015, Jarzyna et al. 2016) to remove the Groningen effect and obtain the proper resistivity value required to calculate water/hydrocarbon saturation. Unfortunately, in some situations, correct measurements are difficult to obtain due to unfavorable geological conditions.

\section{RESISTIVITY LOGGING IN POLAND - DEPOSITS REVEALING THE GRONINGEN EFFECT}

For many years, the focus of hydrocarbon prospection activity in Poland was mainly in the Polish Lowland area (Fore-Sudetic Monocline) (Fig. 1). The largest hydrocarbon reserves in this area occur in carbonates, i.e. the Main Dolomite and Zechstein Limestone, and in the Rotliegend sandstones. The Zechstein limestones and Rotliegend sandstones are usually shielded in the top part of the formation with high-resistivity layers such as anhydrite or salt (halite). Additionally, the Main Dolomite that is isolated from the top, is also isolated from the bottom with Werra anhydrite (Górski et al. 1996, Mamczur et al. 1997, Piesik-Buś 2018). The thickness of the salt ranges from between 30-600 m, anhydrites - between few meters to $300 \mathrm{~m}$, and the productive beds are between 13-85 m (Górski et al. 1996, Piesik-Buś 2018). A very high variability in the resistivity is observed, ranging from $0.1 \Omega \cdot \mathrm{m}$ in porous, water saturated layers up to $40 \mathrm{k} \Omega \cdot \mathrm{m}$ in evaporites. In the geological situation, when the low-resistivity layers are under high-resistivity beds, electrical focused measurements tend to overestimate deep resistivity values. This effect has been known for years by the term Groningen effect, after the largest European gas field in the Netherlands where it was first identified in electrical logs. In Poland, this phenomenon is also known as the shielding effect.

The overvaluation of LLD resistivity values in Dual Laterolog is primarily due to imperfections in the assumptions of the measurement method (Schlumberger 1970, Trouiller \& Dubourg 1994). A simplified pattern of the current flow lines during the resistivity measurement in a homogeneous formation is presented in Figure 2. The focused current is pushed into the formation, and the current lines pass uniformly towards electrode $B$. The reference electrode $\mathrm{N}$ has a similar potential to the return electrode $\mathrm{B}$. It is assumed that the potential between measuring and control electrodes should be close to zero (Woodhouse 1978). In Figure 3 there is the simplified pattern of current flow lines of the deep resistivity measurement (LLD) when a thick high-resistivity layer is presented between the measuring tool in the borehole and electrode B on the surface. The current flowing from the tool moves towards the electrode B on the surface using the "easiest path of resistance", through the mud and casing instead of the rock complex with its higher resistivity. During the measurement, when electrode $\mathrm{N}$ begins to approach the high resistivity complex, the density of the current lines of the focused current artificially increases the apparent resistivity of the formation measured. This is due to a greater loss of potential in the electric field than in the case of a homogeneous formation. 


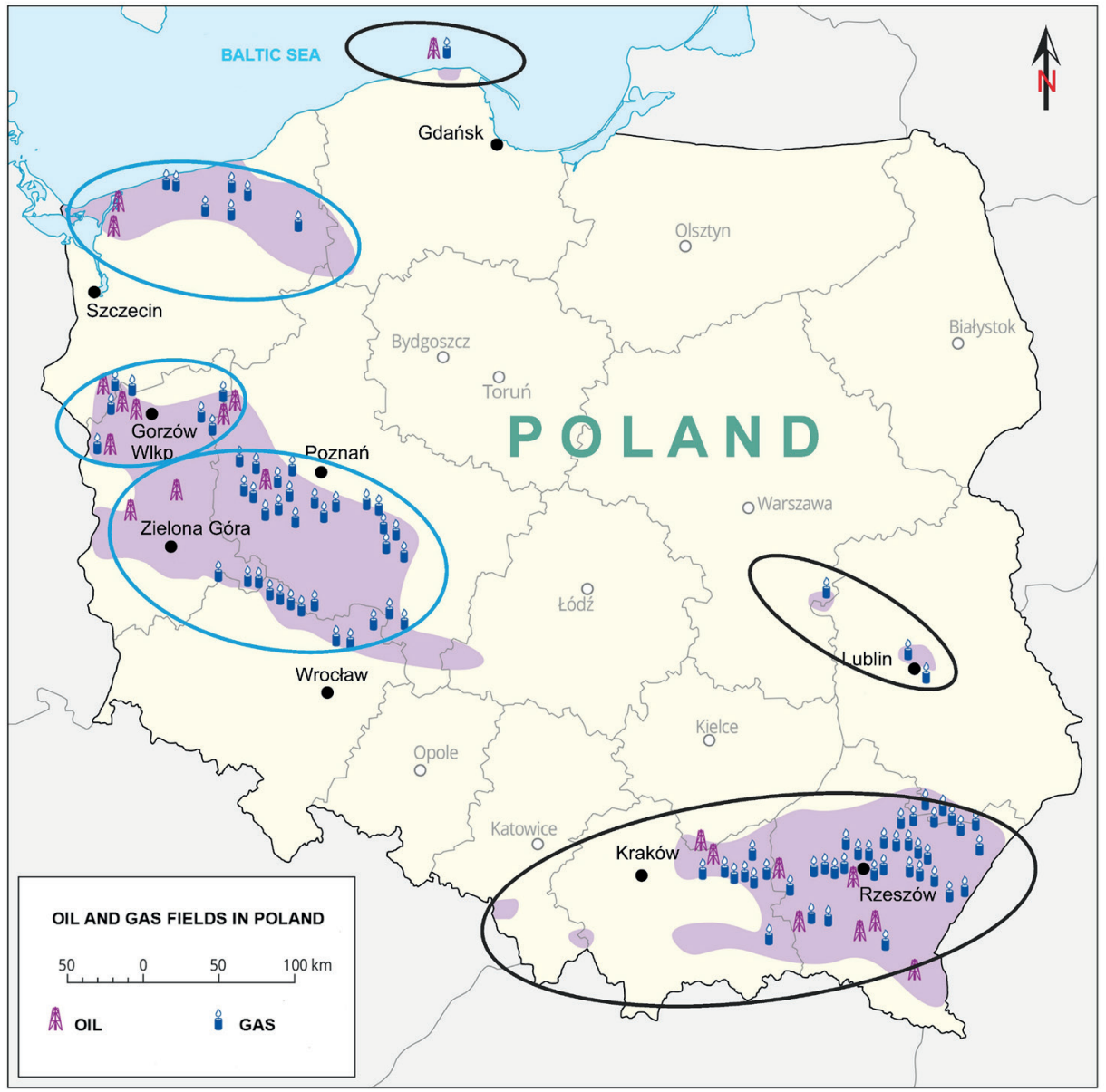

Fig. 1. Map of Poland with locations of main oil and gas deposits marked. The areas marked with a blue ellipse show areas where the Groningen effect has been observed (after https://epodreczniki.pl/a/naturalne-zrodla-weglowodorow/DuWyekael-modified)

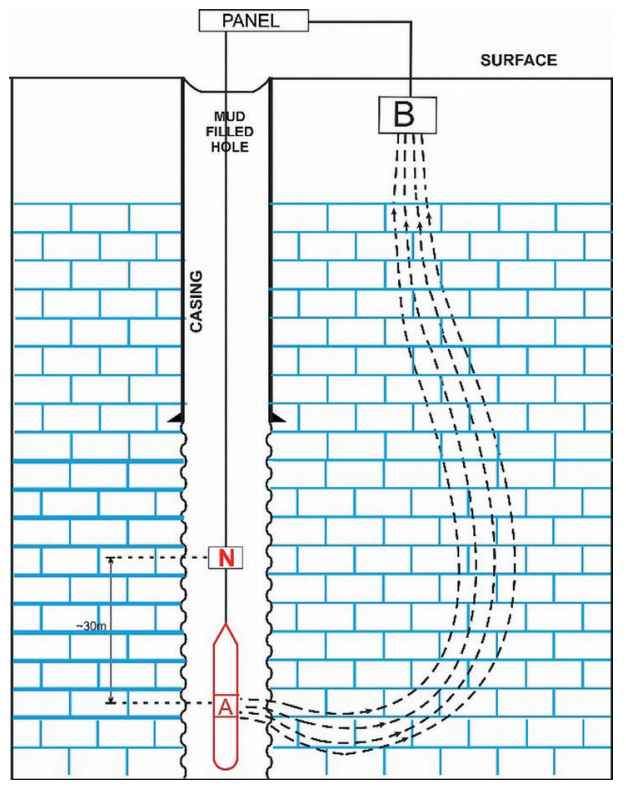

Fig. 2. Focused current lines from Laterolog in a homogeneous formation with low variability of resistivity

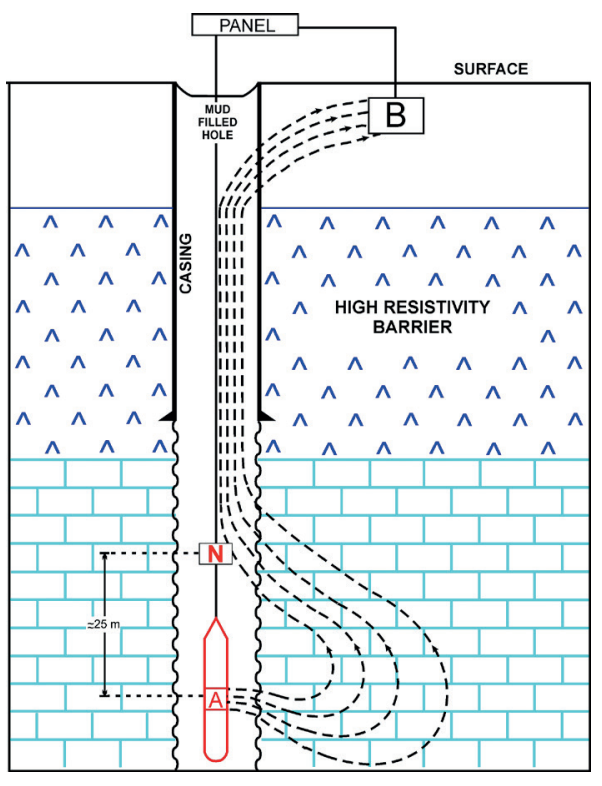

Fig. 3. Focused current lines from Laterolog in the conditions of high-resistivity beds on the top of the reservoir formation (after Woodhouse 1978) 


\section{METHODS FOR IDENTIFYING AND CORRECTING THE GRONINGEN EFFECT IN POLAND}

\section{Constructive/tool design solutions}

During long-term logging operations in the Polish Lowland area, various measurement systems and probes were used to perform resistivity logs. Historically, normal and lateral measuring probes and, subsequently, Laterolog LL3 were applied. The first widely used Laterolog in Poland was the Soviet-type ABK-3 probe. It was built based on the technical solution of the LL3 Laterolog (Schlumberger 1970, Guyod 1984) and consisted of a central electrode $\mathrm{A} 0$ and two elongated shielding electrodes, A1 and A2, which were symmetrical to A0. The current flow through the shielding electrodes generated an electric field that allowed current to flow from electrode $\mathrm{A} 0$ to the formation in a direction perpendicular to the probe. The width of the current lines depended on the width of the central electrode A0. The methodical assumptions used in the first designs of the LL3 probes remain in use to this day, i.e. LL3 is used together with dual induction to determine the resistivity of the flushed zone, Rxo. The problem of the resistivity from the ABK-3 probe overstating in the conditions of low resistivity layers shielded in the top with high resistivity layers was quickly diagnosed by Polish petrophysicists. In 1973, a group of domestic engineers (L. Król, R. Rozesłaniec and S. Sondej) presented an innovative project "Method of the shielding effect eliminating in the ABK-3 device (Laterolog)" (Król 2002). The solution to the problem was seen in a construction change, i.e. including an additional inverted electrode. This solution largely improved the results of measurements, and even eliminated the shielding effect in some geological conditions.

The 1990's in Poland were a period marked by considerable technological change. In this period, the domestic geophysical companies of the Polish Oil and Gas Company (PGNiG) purchased a modern logging system and tools from Halliburton. With new technology solutions like Dual Laterolog available, it was expected that the problems of overstating the resistivity in reservoirs shielded with high resistivity layers would cease to exist. The Dual Laterolog FA (DLL-FA) type had a modified measuring system that allowed for the correction of LLD resistivity measurements, even in the occurrence of the Groningen effect (Chemali \& Dirk 1987). The indicator of the occurrence of the Groningen effect in this instrument was the PHSH parameter, which showed changes in the apparent phase of the measurement voltage, relative to the phase of the measuring current. In the situation when $\mathrm{PHSH}$ parameter changed during the main log, then a second log was performed with the Groningen correction. The Groningen correction meant the modification of the position of reference point $\mathrm{N}$ on the torpedo (Fig. 4). The new reference point, $\mathrm{N}$, was located closer to the tool and this shorter distance between $\mathrm{A} 0$ and $\mathrm{N}$, together with an appropriately modified measuring system, were able to prevent the negative potential from accumulating during the measurement when $\mathrm{N}$ electrode moved from the low resistivity to high resistivity formation (Fig. 4). In the Groningen correction measurement, the reference electrode N' was located about one meter above the top of the tool string (GR/DLL/MSFL). The new construction lowered the depth of investigation of the deep resistivity measurement with the LLDG Groningen correction. The LLDG measurement was shallower than LLD for the standard configuration log. Measurements made using the DLL-FA Laterolog with the Groningen correction system did not give satisfactory results in Polish conditions, so domestic engineers started to find other options for the correction of the LLD log. Based on years of experience in electrical logging using the modified ABK-3 tool with a reversed electrode, a similar solution was applied with the DLL-FA probe. In 1995, the next modification project was realized (Z. Bociek) "Reverse Electrode (E.O.) of the DLL-FA Laterolog" (Król 2002). The inverted electrode solution carried the reference point $\mathrm{N}$ below the probe (Fig. 5).

The modification of the measurement system was possible due to the availability of the technical documentation of the purchased system and logging tools. DLL with a reverse electrode, called LLDO, became the basic measurement in logging programs in the Polish Lowland. LLDO resistivity logs were to a large extent helpful in the selection of parameters in the process of the interpretation of saturation. 


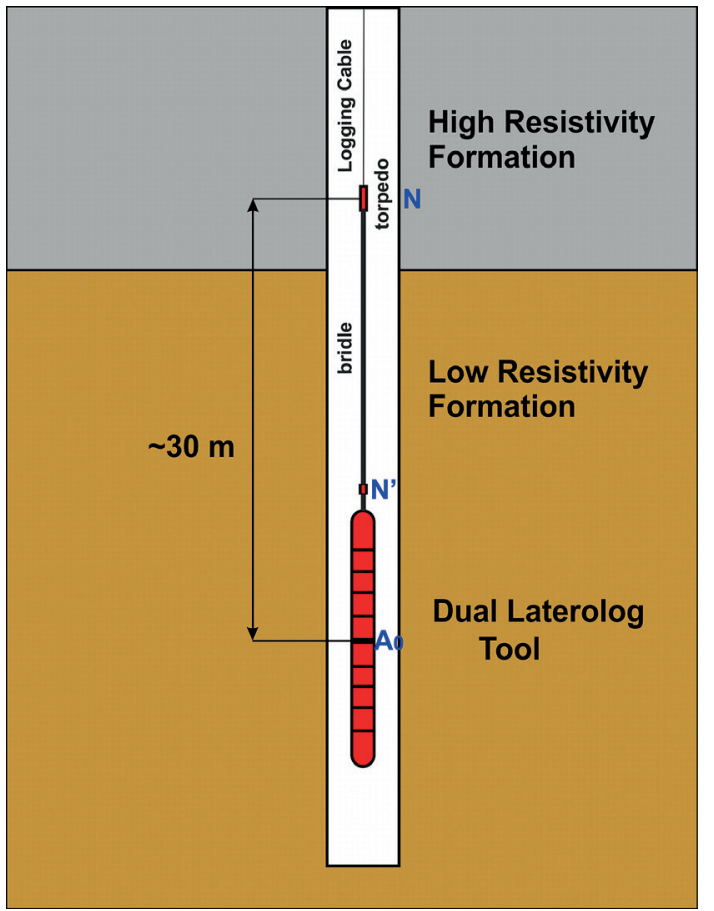

Fig. 4. Typical example of a lithologic layer system where the Groningen effect is generated. Low-resistivity bed of the Main Dolomite or Zechstein Limestone is insulated in the top with high-resistivity anhydrite

Experience in the analysis of the performed measurements revealed a key weakness in the inverted electrode system. In geological profiles where the thickness of the formation was close to the length of the reversed electrode position (A0-N' distance about $30 \mathrm{~m}$, Fig. 5), and isolated from the bottom and top with high resistivity formations, this method failed.

The solution with the reversed electrode did not eliminate the Groningen effect because the electrode remained in a high resistivity formation, below the reservoir. Other cases showed that the LLDO modification could not be applied when the reservoir was only drilled a few meters from the top and there was not enough space for the use of a $25 \mathrm{~m}$ bridle bellow logging tool (Baudzis \& Jarzyna 2018). One construction that was designed to eliminate the Groningen effect was the High Resolution Azimuthal Laterolog Sonde (HALS) by Schlumberger at the beginning of the 1990s. This deep resistivity measurement had a shorter depth of investigation than in LLD compared to standard DLL, due to the use of a half of the length DLT with combination array electrode

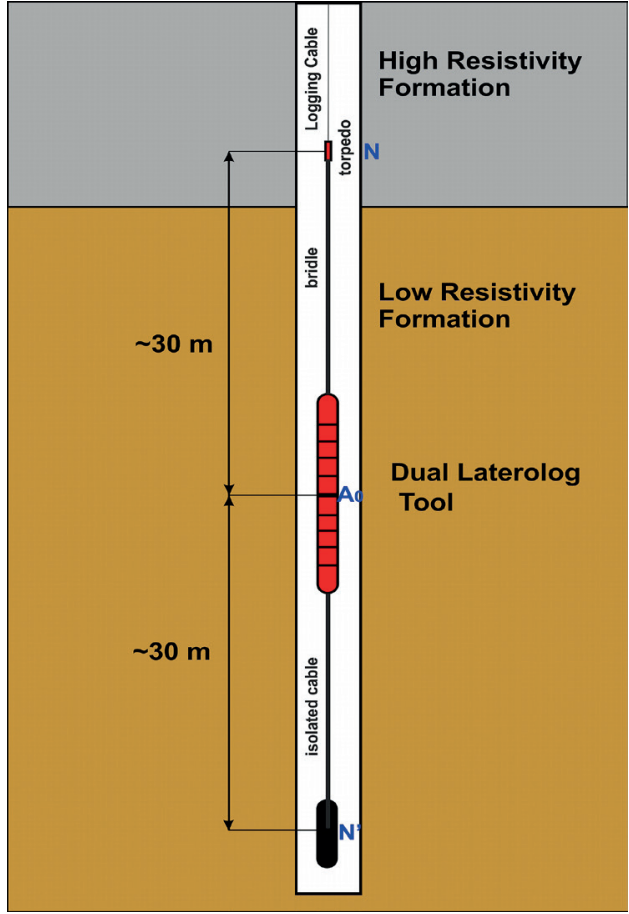

Fig. 5. The modified scheme consisted in transferring the reference point $N$ of the measurement system from above the probe to the bottom of logging tool (N'), using a flexible bridle

system to determination deep and shallow resistivity measurement (Andersen 2001). The next step in the development of Laterolog tools was the High Resolution Laterolog Array (Schlumberger) designed in a similar manner to the high resolution array induction probes (Vallinga \& Yuratich 1993). HRLA did not require an isolating bridle for measurements, and therefore the logs were not burdened with the Groningen effect.

In Figure 6, the HRLA curves (RLA1, RLA2, RLA3, RLA4, RLA5) and the LLS curve (blue) in the third track are compared. The deepest curve (RLA5) range of HRLA depth of investigation is similar or only slightly larger than the LLS log from the standard DLL. In the presented case (Fig. 6), the saturation interpretation performed on the LLS curve and on the Rt curve computed from HRLA in the Main Dolomite gave similar results. The measurements were made under ideal conditions for Laterolog tools, with a hole diameter of $57 / 8$ ", with salt-saturated mud. Despite this, the short curves (RLA1 and RLA2) differ significantly from the values measured by the MSFL tool (track $\left.5^{\text {th }}\right)$. 


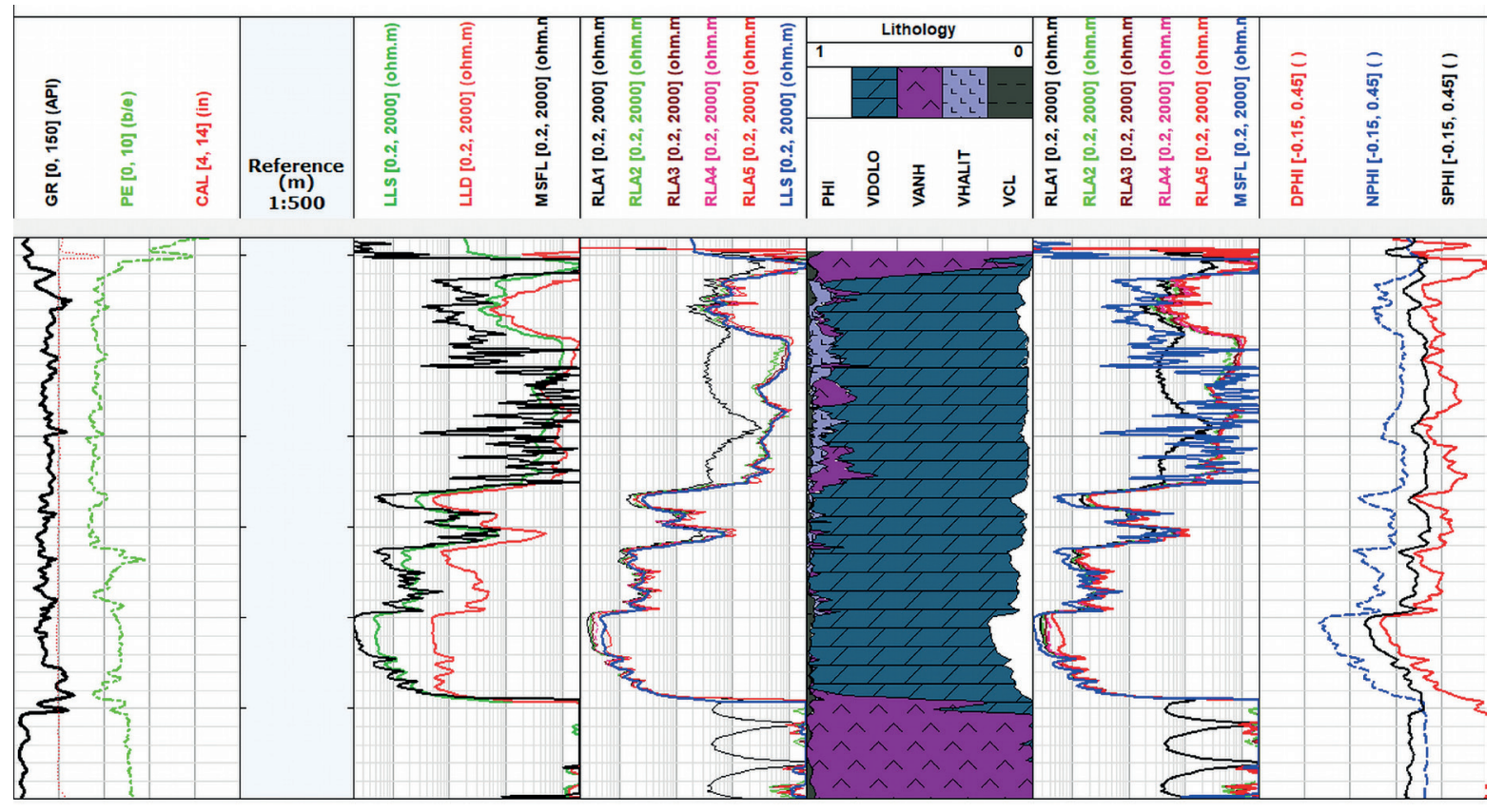

Fig. 6. Sample of well logs recorded in the Main Dolomite; Dual Laterolog (curves LLD, LLS) and MSFL and High Resolution Laterolog Array Tool (RLA1, RLA2, RLA3, RLA4, RLA5, GR - natural gamma radioactivity, Pe - photoelectric absorption index, CAL - caliper, PHI - total porosity, VDOLO, VANH, VHALIT, VCL - volume of dolomite, anhydrite, halite, shale, respectively, obtained from the comprehensive interpretation of well logs, DPHI, NPHI, SPHI - porosity from density, neutron and sonic log, respectively

The difference may be due to the fact that the MSFL pad is pressed against the wall of the borehole, while the HRLA probe is centralized in the well, and short range curves are more susceptible to the influence of low-resistance mud.

Recently, a new technical solution from Halliburton for induction type tools - the Array Compensated Resistivity Tool (ACRt) - was made available for resistivity logging (Halliburton 2005). In accordance with the tool specifications, resistivity measurements can be performed in boreholes filled with saline drilling fluid, and those of a smaller diameter (Fig. 7).

The next example (Fig. 8) includes the DLL/ MSFL resistivity curves - LLD, LLS, MSFL (second track) together with the curves from Array Compensated Resistivity Tool (ACRt) - RT10, RT 20, RT30, RT60, RT90 (third track). It is distinctly visible that the LLS log revealed the highest apparent resistivity, which means a larger depth of investigation than the longest ACRt curves (RT60, RT90) in the hydrocarbon saturated bed. Perhaps an ACRt probe measurement in such environment/borehole conditions in the hydrocarbon saturated bed (the mineralization of the borehole fluid $-168 \mathrm{~g} / \mathrm{dm}^{3}$, and the diameter of the borehole $-57 / 8^{\prime \prime}$ ) is not the best solution. However, we get qualitative information about the Groningen effect and know that we should not use the LLD curve from the DLL. The MSFL log also seems to be the necessary measurement to determine the saturation of the formation. The resistivity of the flushed zone Rxo calculated from the short range ACRt curves (RT10, RT20) looks to be too high.

As already shown, the use of the latest measuring technology does not guarantee that the correct Rt value from field measurements in a Groningen effect environment can be used directly in the saturation interpretation. The data analysis also revealed some information gaps. New tools (Array Laterolog or Array Induction) in Groningen effect conditions have a maximum investigation range which is similar to LLS. The range of LLD from Dual Laterolog is still the deepest, but the resistivity is burdened with the surroundings beds, and is unsuitable for the saturation interpretation of the deposit zone. 


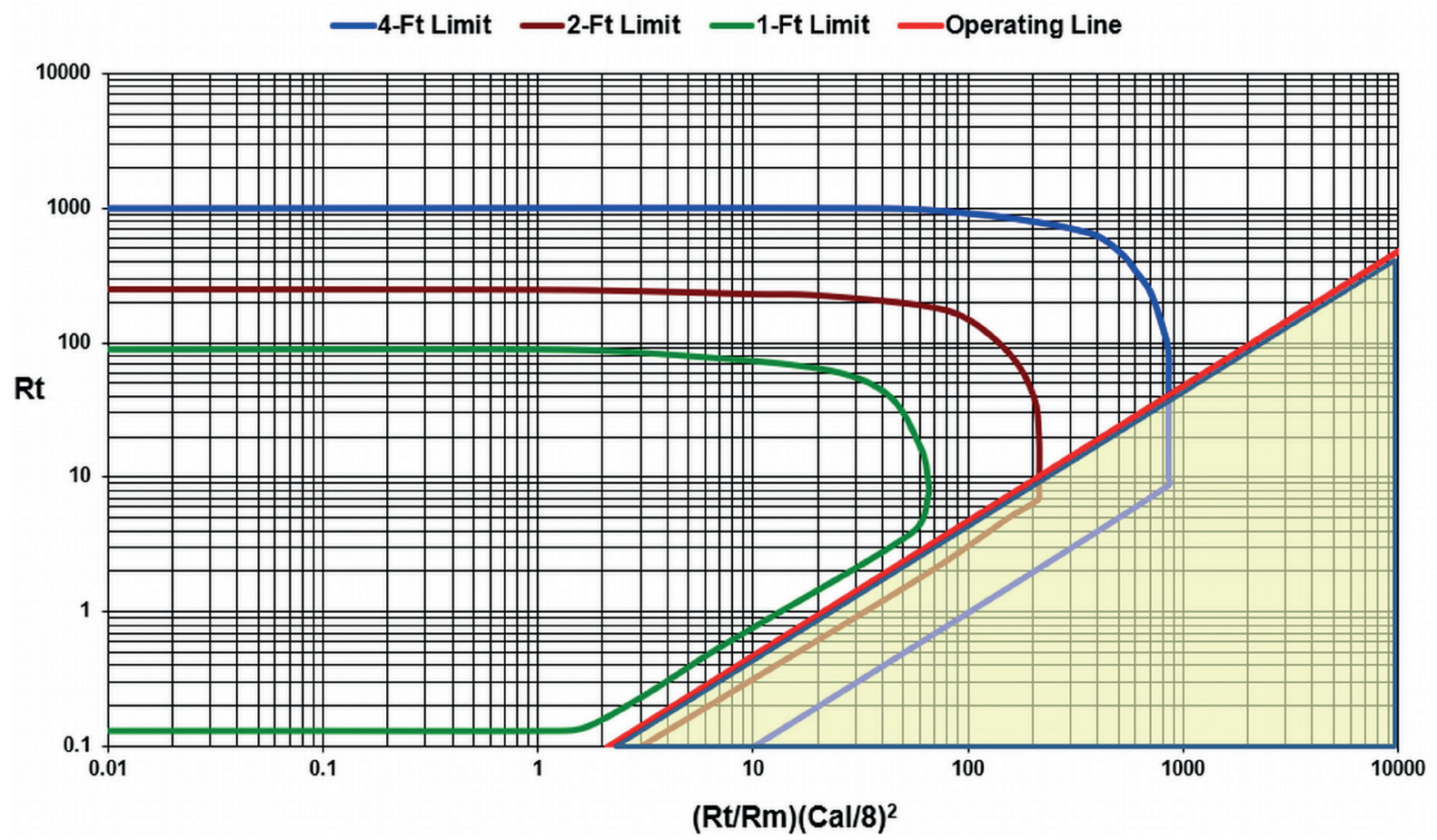

Fig. 7. Array Compensated Resistivity Tool - preferred operation range from ACRt planner (After Halliburton ACRt planner); 4, 2, 1 Ft limit means applicability area for 4, 2, 1 Ft vertical resolution readings. The area below the red line (yellow triangle) indicates the possibility of using the ACRt probe in a salted mud borehole. It is visible that only use 2 and 4 Ft Limit curves can be used; Rt - true resistivity, Rm - mud resistivity, Cal - Caliper, 8 - reference well diameter 8"

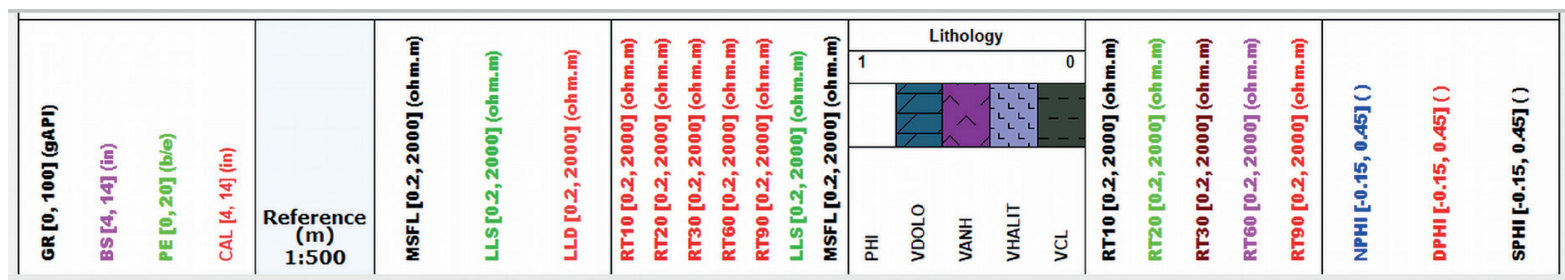

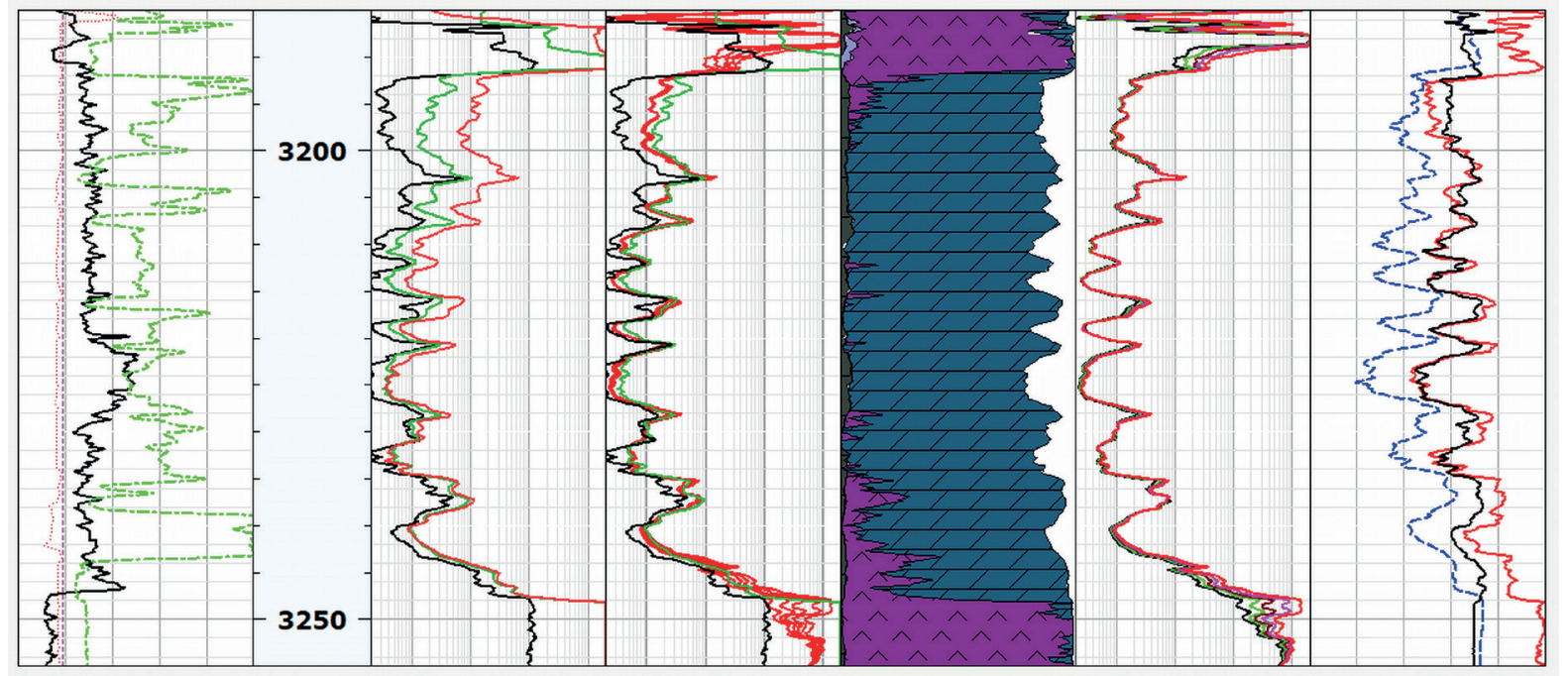

Fig. 8. Sample of well logs from one borehole in the Main Dolomite; Dual Laterolog (curves LLD, LLS) and MSFL) and Array Compensated Resistivity Tool (RT10, RT20, RT30, RT60, RT90), GR - natural gamma radioactivity, Pe - photoelectric absorption index, CAL - caliper, PHI - porosity, VDOLO, VANH, VHALIT, VCL - volume of dolomite, anhydrite, halite, shale, respectively, obtained from the comprehensive interpretation of well logs, DPHI, NPHI, SPHI - porosity from density, neutron and sonic log, respectively 


\section{Computer modeling solutions}

In the face of such imperfections in well logging measurement, scientists and engineers proposed clarifying the phenomenon of the overstating of resistivity by modeling the responses of electrical probes in a simulated environment similar to the real one in which the Groningen effect is generated (Anderson 2001, Yang et al. 2007, Jarzyna et al. 2016). Numerical modeling began to develop quickly along with access to computers with faster and faster processors which were able to quickly obtain outcomes. The process of building a model and achieving the expected results is time-consuming, but if the results are satisfactory the algorithm could be applied to real problems and provide a solution in a short time. Many models describing the current flow in the Earth's crust have been described in the literature (Nam et al. 2010, Cichy \& Ossowski 2015, Drahos \& Galsa 2015, Xiao-Wei et al. 2017). Analytical solutions of the Laplace equation describing the electric field distribution in resistivity logging are complicated by the geological structure and invasion zone around the borehole. These methods also require numerical representations of Bessel functions as series or numerical evaluation of integrals. Finite difference or finite element methods are efficient routines used for the mathematical modeling of physical problems (the Laplace equation in the discussed case) with complicated boundary conditions.

The Poprawki software was built on the basis of the Coulomb's charge method (Cichy \& Ossowski 2015) applied to a Laplace equation in order to obtain the electric field distribution in a rock medium with internal boundaries between layers of different resistivity. The Coulomb charge method was applied to calculate resistivity measured by a Dual Laterolog device in a non-homogeneous medium to obtain relationships between apparent LLD and LLS resistivity as a function of D/d, Rxo/Rm and $\mathrm{Rt} / \mathrm{Rm}$. The modeling results were used to construct nomograms similar to those used by commercial companies (Jarzyna et al. 2016). Using these nomograms, a procedure of corrections was implemented using the Poprawki software. The software was created following the detailed analyses of the Polish cases of the Groningen effect on the basis of data released by PGNiG SA (Jarzyna et al. 2014). Firstly, two linear corrections in the sequence can be applied to apparent resistivity of LLD and LLS: (1) to reduce borehole influence and (2) to correct the influence of the interpreted bed thickness and shoulder bed resistivity. A third correction, (3) removes invasion effects using special tornado-type charts (Fig. 9).

The results of resistivity curves processed using Poprawki software are presented in Figures 10 and 11. The first example (Fig. 10) illustrates the final result as Rt curve in the Main Dolomite, hydrocarbon saturated bed. The reservoir layer is insulated from the top and bottom. The Rt curve, after full corrections applied using the Poprawki software, is slightly lower in comparison to the apparent resistivity from the LLD reading. Hydrocarbon saturation calculated on the basis of the Rt curve was confirmed by the production test.

The correction procedures of the Poprawki software were applied to the RLA resistivity curves recorded together with DLL in the selected depth section. The Main Dolomite bed was water saturated, with an interval of only a few meters at the top of reservoir showing hydrocarbons. The reservoir bed was insulated from the top and bottom by adjacent beds of high resistivity anhydrites. Two sets of apparent resistivity curves (MSFL, LLS, LLD and RLA1, RLA3, RLA5) were processed using Poprawki software in the same way (shoulder bed corrections from two sides). The results of the Poprawki processing for the second data set are presented in the $5^{\text {th }}$ track. This was an experimental application of RLA5 as LLD, RLA3 as LLS and RLA1 as MSFL. The true resistivity of the formation, Rt, was obtained in the experiment on the basis of the RLA5 curve (right track in Figure 11) and presents distinctly lower values in comparison to the Rt from the DLL data set. The Poprawki correction experiment confirms the earlier presented conclusion that the RAL5, the resistivity curve with the highest range of investigation, cannot be compared with LLD, but with LLS.

Apart from computer modeling, other statistical methods such as artificial neural networks (ANN) can be helpful in Rt determination in an environment with high and low resistivity layers. Statistical methods are certainly an effective and helpful tool, but they are labor-intensive and require knowledge of the exact construction of the network model. 
A

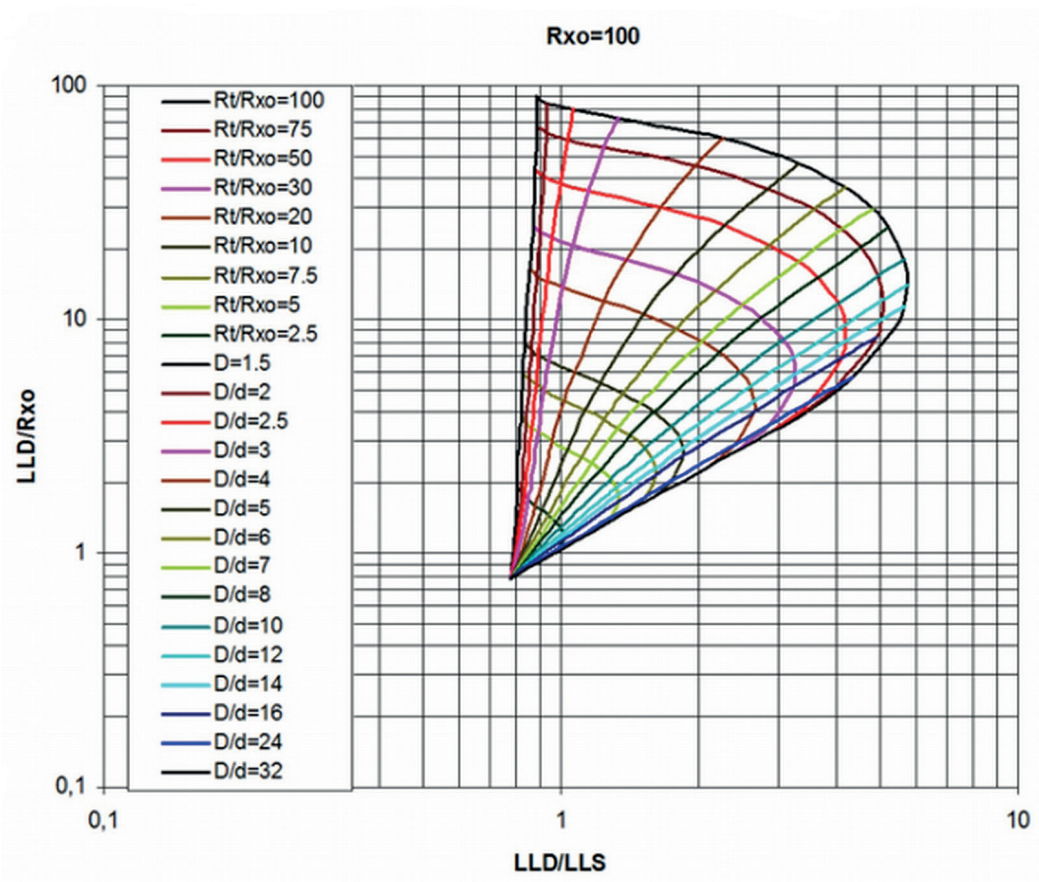

$\mathrm{B}$

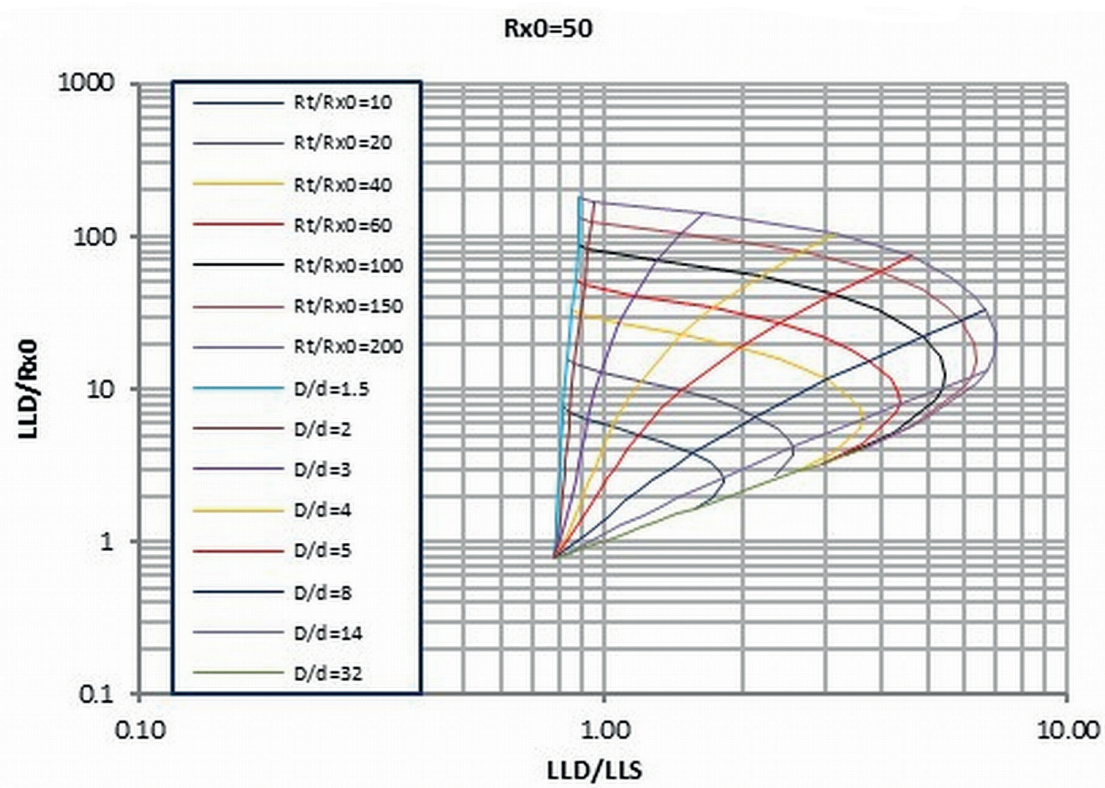

Fig. 9. Example of a tornado chart: A) $R x 0=100 ; B) R x 0=50$; Rt - true resistivity, Rxo-flushed zone resistivity, LLD and LLS deep and shallow laterolog operating modes apparent resistivity, $d$ - borehole diameter, $D$ - invaded zone diameter

Well logging with a huge amount of data in a well-known deposit is a good subject upon which to undertake the statistical approach, but in the case of drilling exploration wells in a new oil-gas field, these methods will not work because of the lack of the necessary data.

Primary analyses using ANN were done on well logging data from four selected boreholes in the
BMB deposit in the Polish Lowland (Puskarczyk \& Baudzis 2018). Satisfactory results were obtained in Rt prediction using multilayer perceptrons. Networks were constructed and learned on the basis of well logging data from one borehole, representative of the BMB deposit in the litho-stratigraphic section of the Main Dolomite sited between the Basal Anhydrite (from bottom) and Main Anhydrite (from top). 


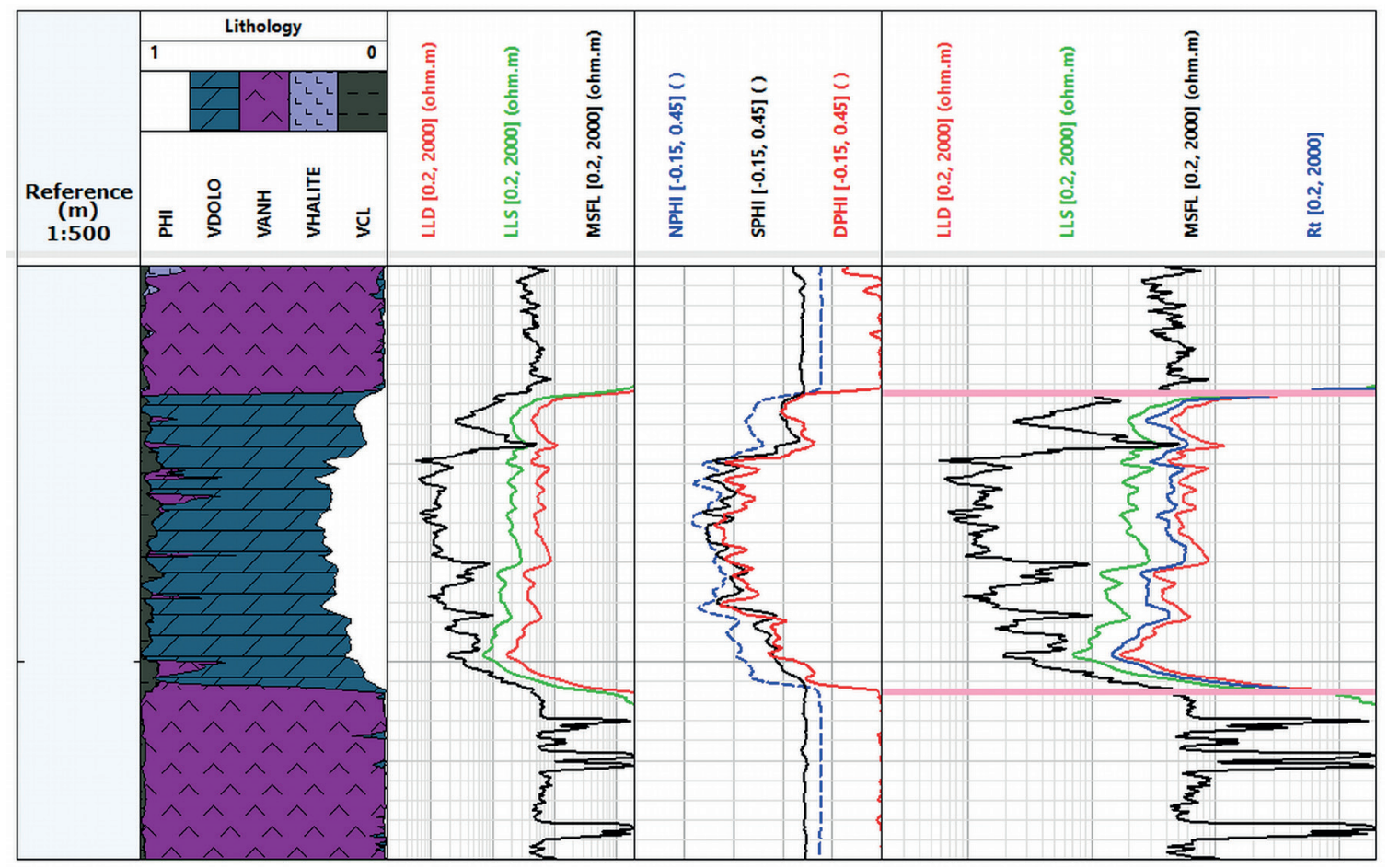

Fig. 10. Results of well logging measurements and interpretation in the investigated Main Dolomite hydrocarbon saturated bed, with a curves description similar to Figure 6. Horizontal magenta lines in the $5^{\text {th }}$ track indicate the considered interval for Rt calculation. The Rt curve (blue color) was determined using the Poprawki software

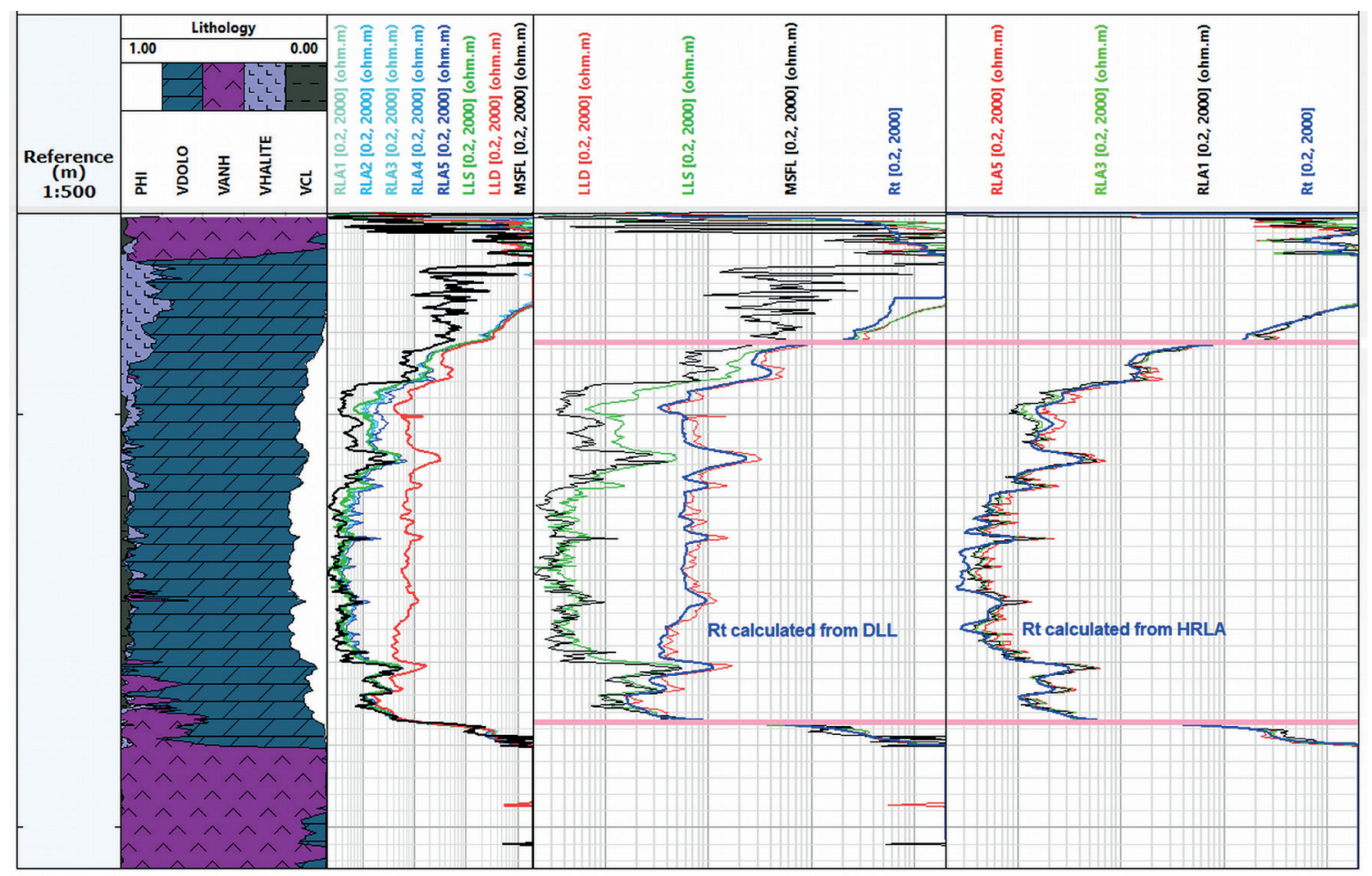

Fig. 11. Comparison of the resistivity curves correction results; in the $4^{\text {th }}$ track there are Dual Laterolog curves after Poprawki processing, in the $5^{\text {th }}$ track - the results of the Poprawki application to the RLA (RLA5 as LLD, RLA3 as LLS and RLA1 as MSFL); curves descriptions similar to those in Figures 6 and 10. The Rt curves (blue color in $4^{\text {th }}$ and $5^{\text {th }}$ tracks) were calculated using Poprawki software. Horizontal magenta lines in the $4^{\text {th }}$ and $5^{\text {th }}$ tracks indicate the considered interval for Rt calculation 


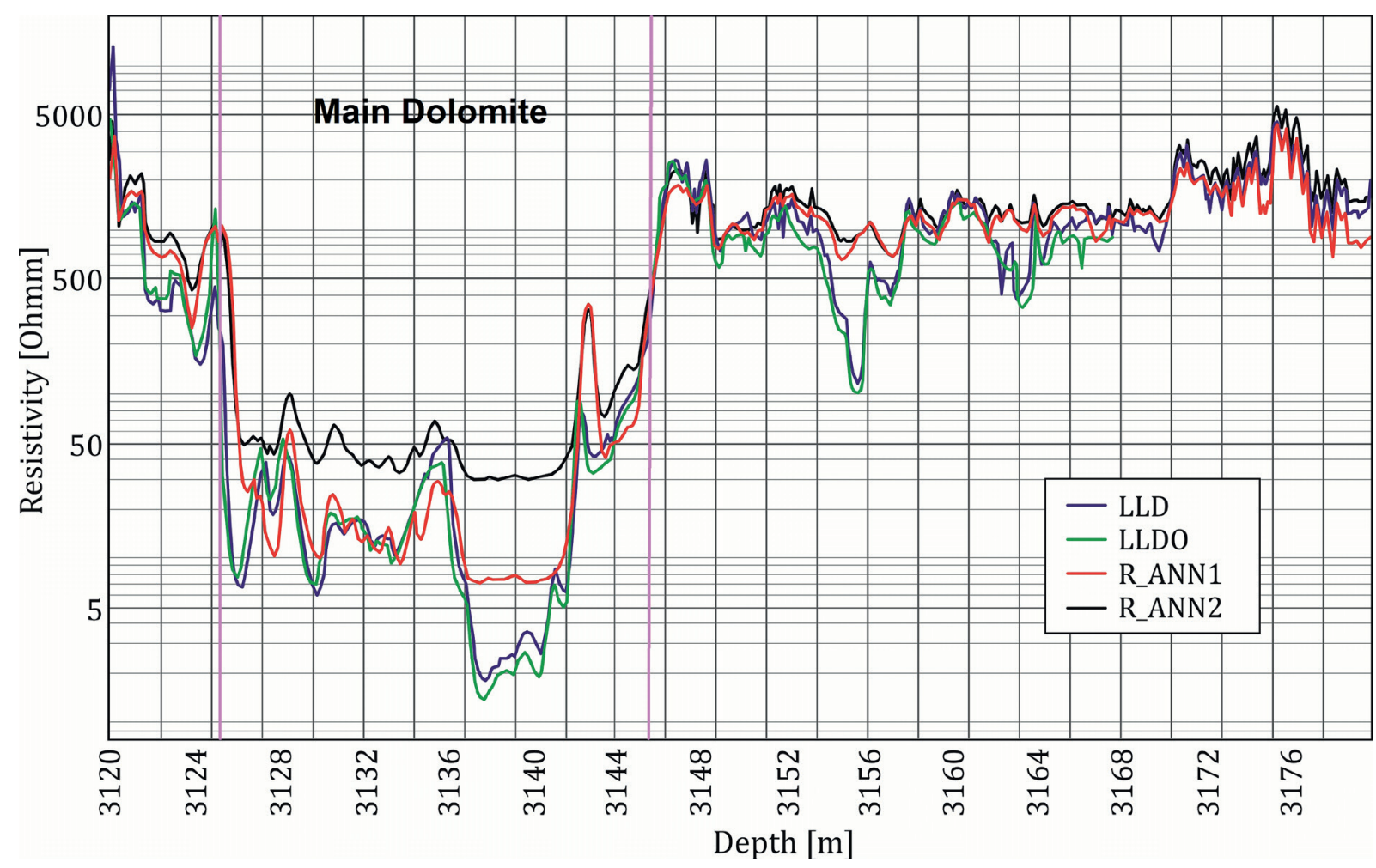

Fig. 12. ANN modeling results compared with measured standard Dual Laterolog long range LLD log, and Dual Laterolog with the reverse electrode LLDO log; $R \_A N N 1$ - ANN resistivity modeling result, good matching in the Main Dolomite, $R \_A N N 2$ ANN resistivity modeling result, bad matching in the Main Dolomite (after Puskarczyk \& Baudzis, modified)

Synthetic R_ANN curves were determined on the basis of the following logs: resistivity - LLD, LLS, standard natural radioactivity - GR, acoustic transit interval time - DT, bulk density - RHOB, neutron porosity - NPHI, volume of potassium, uranium and thorium, respectively - POTA, URAN and THOR. A comparison of raw LLD and LLDO curves (from DLL with the reverse electrode) with R_ANN1 (good match) and R_ANN2 (poor match) in the Main Dolomite section from one of the analyzed boreholes is presented in Figure 12. True resistivity curve R_ANN1 runs parallel to LLD and LLDO. The obtained true resistivity of the uninvaded zone enabled the correct calculation of water/hydrocarbon saturation $\mathrm{Sw} / \mathrm{Sh}$, as confirmed by a borehole tester. In the interval 3142-3136 m, we can see that the calculated R_ANN curve differs significantly from the measured LLD and LLDO values. Failure to adjust in this interval may be due to the fact that the bottom part of the Main Dolomite in the tested structure was fully saturated with water, while in other wells they were saturated with hydrocarbons.

\section{SUMMARY AND CONCLUSIONS}

The general information about the Groningen effect and its influence on the deep apparent resistivity logged using LLD and the described technical and numerical solutions illustrate the efforts of Polish engineers/practitioners to properly calculate hydrocarbon saturation in specific litho-stratigraphic conditions in deposits located in the Main Dolomite formation of the Polish Lowland. The probe construction modifications proposed by Geofizyka Torun SA enabled the Groningen effect to be eliminated in the selected cases. A comparison of Dual Laterolog (DLL) resistivity curves with readings of new resistivity probes such as High Resolution Laterolog (HRLA) or High Resolution Induction (Array Compensated Resistivity Tool, ACRt) logged to eliminate the Groningen effect showed that they do not fully meet expectations in the elimination of the Groningen effect. It was shown that the deep investigation resistivity from HRLA and ACRt, which should correspond to Rt in extreme 
geological conditions, is similar to a shallow LLS reading of the standard Dual Laterolog. Computer modeling provided a new generation of corrections to resistivity disturbed by the Groningen effect. Applying the Poprawki software allows the proper Rt value to be obtained and which will work as the basis for correct water/hydrocarbon saturation calculation. Using ANN to determine the true resistivity of the uninvaded zone (which is free from the Groningen effect) is an additional proposition for the interpretation in well-known deposits with many wells. A combined approach, comprising specially selected measurement methods and ways of processing the raw resistivity curves, will result in a modified methodology of water/hydrocarbon saturation determination in the difficult Groningen effect cases. The Poprawki software may be applied to archival data, allowing LLD curves burdened with the Groningen effect to be improved and permitting the reinterpretation of old data.

The authors would like to thank POGC, Warsaw, Poland and Geofizyka Torun S.A. for access to their data.

\section{REFERENCES}

Andersen B.I., 2001. Modeling and inversion methods for the interpretation of resistivity logging tool response. Delft University of Technology [Ph.D. Thesis].

Baudzis S. \& Jarzyna J., 2018. Improvement of Measurement and Interpretation of LLD Resistivity Log in the Polish Cases of Groningen Effect Formations. [in:] $80^{\text {th }} E A G E$ annual conference \& exhibition 2018: 11-14 June 2018, Copenhagen, Denmark, https://doi.org/10.3997/2214-4609. 201800959.

Boyeldieu C. \& Winchester A., 1982. Use of the Dual Laterolog for the Evaluation of the Fracture Porosity in Hard Carbonate Formations. [in:] Offshore South East Asia Show, 9-12 February, Singapore, SPE-10464-MS, Society of Petroleum Engineers, https://doi.org/10.2118/10464-MS.

Chemali R.E. \& Dirk W.C., 1987. Method and Apparature for Measuring Resistivity of an Earth Formation. U.S. Patent $4,646,026$.

Cichy A. \& Ossowski A., 2015. Modeling Electrical Field Distribution in Layered Geological Rock Formations with a Borehole Using the Coulomb Charges Method. Acta Geophysica, 63, 5, 1244-1255, https://doi.org/10.2478/ s11600-014-0253-2.

Cozzolino K. \& Jadir da Conceicao da Silva, 2007. Synthetic focusing and simulation of dual laterolog tool in axisymmetric subsurface models. Journal of Applied Geophysics, 61(2), 102-110, https://doi.org/10.1016/ j.jappgeo.2006.05.001.
Drahos D. \& Galsa A., 2015. Modeling Groningen effect on deep laterolog. Geosciences and Engineering, 4, 9-21.

Ellis Darwin V. \& Singer Julian M., 2008. Well Logging for Earth Scientists. 2nd ed., Springer.

Górski M., Trela M., Tomaszewska J. \& Górska W., 1996. Opracowanie badań sejsmicznych 3D w rejonie Barnówko-Lubiszyn [industry Report - Arch. PGNiG S.A., Warsaw, Poland].

Guyod H., 1984. Factors Affecting the Responses of Laterolog-Type Logging Systems (LL3 and LL7). Journal of Petroleum Technology, 16, 02, SPE-714-PA, https:/doi. org/10.2118/714-PA.

Halliburton, 2005. Array Compensated Resistivity Tool $\left(\right.$ ACR $\left.^{\mathrm{Tm}}\right)$. Halliburton.

Jarzyna J.A., Bała M., Baudzis S., Cichy A. \& Ossowski A., 2014. Modelowanie odpowiedzi sterowanych sond do profilowania oporności $w$ zróżnicowanych ośrodkach geologicznych dla poprawienia wyznaczania oporności rzeczywistej warstw [project documentation - AGH University of Science and Technology, Kraków, Poland/PGNiG SA, Warsaw, Poland].

Jarzyna J.A., Cichy A., Drahos D., Galsa A. Bala M.J. \& Ossowski A., 2016. New Methods for Modeling Laterolog resistivity Corrections. Acta Geophysica, 64, 2, 417-442, https://doi.org/10.1515/acgeo-2016-0012.

Klein J.D., Martin P.R. \& Allen D.F., 1997. Petrophysics of electrically anisotropic reservoirs, The Log Analyst, 38, 25-36.

Król L., 2002. Historia rozwoju geofizyki wiertniczej w Toruńskiej Geofizyce. [in:] Kiełt M. (red.), VIII Krajowa Konferencja Naukowo-Techniczna: Zastosowanie metod $i$ danych geofizyki wiertniczej $w$ górnictwie naftowym, sejsmice i geologii, Szymbark, 23-26 IX 2002, V.I, 3-36.

Mamczur S., Radecki S. \& Wojtkowiak Z., 1997. O największym złożu ropy naftowej w Polsce Barnówko-Mostno-Buszewo (BMB). Przegląd Geologiczny, 45, 6, 582-588.

Nam M.J, Pardo D. \& Torres-Verdin C., 2010. Assessment of Delaware and Groningen effect on dual-laterolog measurements with a self-adaptive hp finite-element method. Geophysics, 75, 6, 143-149.

Piesik-Buś W. 2018. Bilans stanu zasobów gazu ziemnego na przykładzie złóż Niżu Polskiego. Nafta-Gaz, 7, 543-551, https://doi.org/10.18668/NG.2018.07.08.

Puskarczyk E. \& Baudzis S., 2018, Wykorzystanie sztucznych sieci neuronowych do odtworzenia brakujących danych i poprawy niejednoznacznych wyników, na przykładzie profilowań geofizyki otworowej. [in:] Geopetrol 2018: rozwój technik poszukiwania i eksploatacji złóż węglowodorów: Zakopane-Kościelisko, 17-20.09.2018: materiały konferencyjne, Instytut Nafty i Gazu - Państwowy Instytut Badawczy, Kraków, 281-286.

Rocha H., Costa J.S., Carrasquilla A. \& Carrasco A., 2019. Petrophysical characterization using well log resistivity and rock grain specific surface area in a fractured carbonate pre-salt reservoir in the Santos Basin, Brazil. Journal of Petroleum Science and Engineering, 183, 106372, https://doi.org/10.1016/j.petrol.2019.106372.

Schlumberger, 1970. The Dual Laterolog. Schlumberger, Houston, Texas.

Sibbit A.M. \& Faivre O., 1985. The Dual Laterolog Response in Fractured Rocks. [in:] SPWLA $26^{\text {th }}$ Annual Logging Symposium, 17-20 June, Dallas, Texas, SPWLA-1985-T, Society of Petrophysicists and Well Log Analysts, Austin, Texas. 
Smits J.W., Benimeli D., Dubourg I. et al., 1995. High Resolution from a New Laterolog with Azimuthal Imaging. [in:] SPE Annual Technical Conference and Exhibition, Dallas, Texas, 22-25 October 1995, SPE-30584-MS, https://doi.org/10.2118/30584-MS.

Smits J.W., Dubourg I., Luling M.G. et al., 1998. Improved Resistivity Interpretation Utilizing a New Array Laterolog Tool and Associated Inversion Processing. [in:] SPE Annual Technical Conference and Exhibition, New Orleans, Louisiana, 27-30 September 1998, SPE-49328-MS Society of Petroleum Engineers, https://doi.org/10.2118/ 49328-MS.

Szijártó M., Balázs L., Drahos D. \& Galsa A., 2017. Numerical sensitivity test of three-electrode laterolog borehole tool. Acta Geophysica, 65, 701-712.

Trouiller J.C. \& Dubourg I., 1994. A Better Deep Laterolog Compensated for Groningen and Reference Effects. [in:] SPWLA 35 ${ }^{\text {th }}$ Annual Logging Symposium, 19-22 June, Tulsa, Oklahoma, SPWLA-1994-VV, Society of Petrophysicists and Well Log Analysts, Austin, Texas.

Vallinga P.M. \& Yuratich M.A., 1993. Accurate Assessment of Hydrocarbon Saturations in Complex Reservoirs from Multi-Electrode Resistivity Measurements. [in:]
SPWLA 34 $4^{\text {th }}$ Annual Logging Symposium, 13-16 June, Calgary, Alberta, SPWLA-1993-E, Society of Petrophysicists and Well Log Analysts, Austin, Texas.

Vasvari V., 2011. On the applicability of DLL for the determination of fracture parameters in hard rock aquiffery. Austrian Journal of Earth Sciences, 104/2, 80-89.

Woodhouse R., 1978. The laterolog Groningen phantom can cost you money. [in:] SPWLA $19^{\text {th }}$ Annual Logging Symposium, 13-16 June, El Paso, Texas, SPWLA-1978-R, Society of Petrophysicists and Well Log Analysts, Austin, Texas.

Xiao-Wei, Si-Hui Xu, Guan-You Xu, Xuan-Feng, Jiaming Feng \& Di-Ren Liu, 2017. Numerical simulation of dual laterolog response in directional wells and development of correction plate. Open Journal of Yangtze Gas and Oil, 2, 237-248, https://doi.org/10.4236/ojogas.2017.24019.

Yang W., Torres-Verdín C., Akkurt R., Al-Towijri A., Al-Dossari S. \& Ersoz H., 2007. Interpretation of frequency-dependent dual-laterolog measurements acquired in Middle-East carbonate reservoirs using the second-order finite-element method (Expanded Abstract). [in:] SPWLA $48^{\text {th }}$ Annual Logging Symposium, June 3-6, 2007, Society of Petrophysicists and Well Log Analysts, Austin, Texas. 